\title{
Perbandingan Algoritma Pewarnaan LDO, SDO, dan IDO pada Graf Pengaturan Lampu Lalu Lintas di Persimpangan Lima Kota Tua Ampenan
}

\author{
I Gede Wiriana Jaya ${ }^{a, *}$, Ahmad Akram ${ }^{b}$, Moh. Roid Fathani ${ }^{c}$, Nurul Hikmah $^{d}$, Siti Adniati ${ }^{e}$ \\ a,* Program Studi Matematika, FMIPA, Universitas Mataram, Jl. Majapahit No. 62 Mataram, 83125, Indonesia, \\ Email: gedewiriana11@gmail.com \\ ${ }^{\text {b }}$ Program Studi Matematika, FMIPA, Universitas Mataram, Jl. Majapahit No. 62 Mataram, 83125, Indonesia, \\ Email: akraini2013@gmail.com \\ c Program Studi Matematika, FMIPA, Universitas Mataram, Jl. Majapahit No. 62 Mataram, 83125, Indonesia, \\ Email: roidslank@gmail.com \\ d Program Studi Matematika, FMIPA, Universitas Mataram, Jl. Majapahit No. 62 Mataram, 83125, Indonesia, \\ Email: nurulhiks98@gmail.com \\ e Program Studi Matematika, FMIPA, Universitas Mataram, Jl. Majapahit No. 62 Mataram, 83125, Indonesia, \\ Email: sitiadniati46@gmail.com
}

\section{A B S T R A C T}

Colouring point is one of the topics in Theory Graph, which is about colouring all the points on a graph so that the are no two neighbouring points have the same colour. One of the applications is in the traffic light system, which can helps in improving the effectiveness of traffic lights to prevent and overcome congestion problems. The main purpose of colouring point is to use minimum different colours to colour all the points on a graph. The minimum number of colours used is called Chromatic number. The fewer colours used, the more effective the solution. The number of colours in traffic light system shows the number of conditions to manage the traffic lights. There are many different algorithms of colouring points; three of them are LDO, SDO and IDO algorithm. In this paper, we will apply and compare these three algorithms to the graph of traffic lights in crossing five Kota Tua Ampenan. We choose this crossroads because this is one of the crowded crossroads in Mataram city, especially in the morning, working hours and evenings. Based on our research, for this case LDO and IDO algorithm are more effective than SDO algorithm.

Keywords : colouring graph, traffic lights, crossroads, chromatic , degree

* Corresponding author.

Alamat e-mail: gedewiriana11@gmail.com 


\section{A B S T R A K}

Coloring point adalah salah satu topik dalam Teori Graf, yaitu tentang mewarnai semua titik pada grafik, sehingga tidak ada dua titik tetangga yang memiliki warna yang sama. Salah satu aplikasi adalah sistem lampu lalu lintas, yang dapat membantu meningkatkan efektivitas lampu lalu lintas untuk mencegah dan mengatasi masalah kemacetan. Tujuan utama titik pewarnaan adalah menggunakan warna minimum yang berbeda untuk mewarnai semua titik pada grafik. Jumlah minimum warna yang digunakan disebut nomor Chromatic. Semakin sedikit warna yang digunakan, semakin efektif solusinya. Jumlah warna dalam sistem lampu lalu lintas menunjukkan jumlah kondisi untuk mengelola lampu lalu lintas. Ada banyak algoritme titik pewarnaan yang berbeda; tiga di antaranya adalah algoritma LDO, SDO dan IDO. Dalam tulisan ini, kami akan menerapkan dan membandingkan ketiga algoritma ini dengan grafik lampu lalu lintas dalam melintasi lima Kota Tua Ampenan. Kami memilih persimpangan jalan ini karena ini adalah salah satu persimpangan ramai di kota Mataram, terutama di pagi hari, jam kerja dan malam hari. Berdasarkan penelitian kami, untuk kasus ini algoritma LDO dan IDO lebih efektif daripada algoritma SDO.

Kata kunci: pewarnaan grafik, lampu lalu lintas, persimpangan jalan, berwarna, derajat

Diserahkan: 16-05-2019; Diterima: 28-06-2019;

\section{Pendahuluan}

Pewarnaan graf adalah salah satu topik dalam teori graf yang telah banyak diterapkan pada berbagai permasalahan, diantaranya; pewarnaan peta, penyusunan jadwal, dan penyimpanan senyawa kimia berbahaya. Ada tiga macam pewarnaan graf yaitu pewarnaan titik (vertex colouring), pewarnaan sisi (edge colouring), dan pewarnaan wilayah (face colouring). Topik yang dibahas pada penelitin ini adalah pewarnaan titik.

Pewarnaan titik adalah memberi warna pada titik-titik graf sedemikian sehingga tidak ada dua titik bertetangga yang mempunyai warna yang sama. Cara yang paling sederhana untuk menjamin dua titik yang bertetangga memiliki warna yang berbeda adalah dengan mewarnai setiao titik dengan warna yang berbeda. Namun dalam permasalahan pewarnaan graf tidak hanya sekedar mewarnai titik-titik dengan warna berbeda dari titik tetangganya, tetapi juga harus menggunakan warna berbeda sesedikit mungkin, karena dalam penerapan pewarnaan graf jumlah warna yang minimum berarti meminimumkan jumlah sumber daya seperti ruang dan waktu dalam menyelesaikan suatu permasalahan.

Tidak semua graf dapat ditentukan jumlah warna yang digunakan dengan mudah, oleh karena itu dibutuhkan algoritma yang dapat membantu melakukan pewarnaan graf. Algoritma adalah urutan logis langkah-langkah penyelesaian masalah yang disusun secara sistematis. Pada pewarnaan graf, algoritma mengatur bagaimana proses mewarnai suatu graf. Banyak algoritma yang telah dikembangkan untuk membantu menyelesaikan pewarnaan graf. Kali ini akan diberikan tiga algoritma yang dapat digunakan untuk menyelesaikan
Doi: https://doi.org/10.29303/emj.v1i1.23

masalah pewarnaan titik berdasarkan urutan titik yang akan diwarnai yaitu; algoritma Largest Degree Ordering (LDO), Saturated Degree Ordering (SDO), dan Incident Degree Ordering (IDO).

Penerapan pewarnaan graf juga dapat dilihat pada pengaturan lampu lalu lintas, yaitu dengan membentuk graf dari persimpangan yang dijadikan obyek penelitian. Titik pada graf menunjukkan jalurjalur yang diperbolehkan berlaku dari jalan A ke B, sedangkan sisi graf adalah jalur perjalanan yang tidak boleh dilakukan secara bersamaan.

Persimpangan adalah daerah yang kritis pada suatu jalan raya yang merupakan tempat titik konflik dan tempat kemacetan karena bertemunya dua ruas jalan atau lebih. Sehingga dibutuhkan suatu pengaturan pada lalu lintas agar tidak terjadi penumpukan kendaraan atau kemacetan pada persimpangan tersebut. Oleh karena itu, dibuat lampu lalu lintas untuk mengatur arus lalu lintas agar meminimalisir permasalahan-permasalahan tersebut.

Pembahasan pada penelitian ini adalah penggunaan teori graf dalam pengaturan lampu lalu lintas dengan memanfaatkan tiga algoritma pewarnaan titik pada graf, yaitu algoritma LDO, SDO dan IDO.

\section{Landasan Teori 2.1.Pengenalan Teori Graf}

Teori graf adalah bahasan yang sudah lama namun masih memiliki banyak terapanyan hingga sekarang. Teori graf yang pertama kali diperkenalkan adalah tentang masalah jembatan Königsberg pada tahun 1736. Baru pada sekitar tahun 1920 teori graf berkembang pesat karena aplikasinya yang sangat luas dalam kehidupan sehari-hari dan bahkan dalam 
berbagai bidang ilmu seperti Ilmu Komputer, Teknik, Sains, dan Ilmu Sosial.

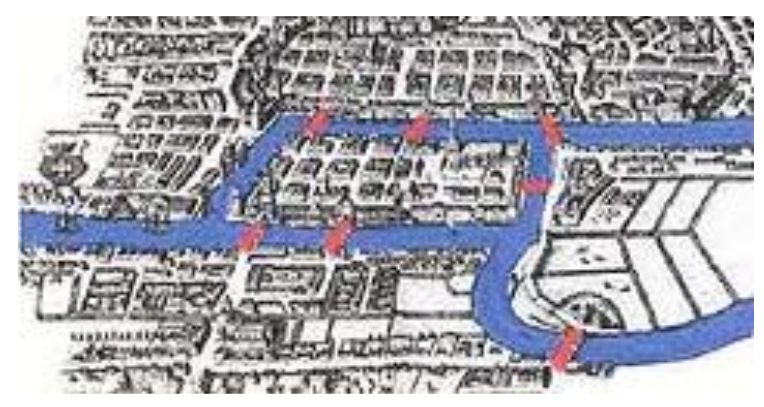

Gambar. 1 - Jembatan Konisberg

Menurut catatan sejarah, masalah jembatan Königsberg adalah masalah yang pertama kali menggunakan graf pada tahun 1736. Di kota Königsberg (sebelah timur negara bagian Prussia, Jerman), sekarang bernama kota Kaliningrad, terdapat sungai Pregal yang mengalir mengitari pulau Kneiphof lalu bercabang menjadi dua buah anak sungai yang diperlihatkan oleh gambar 1 . Permasalahannya ialah untuk menemukan pejalanan atau rute dari suatu kota melalui ketujuh buah jembatan, masing-masing tepat satu kali dilewati, kemudian kembali lagi ketempat awal (Munir, 2016: 354).

\subsection{Definisi Graf}

Graf $\mathrm{G}$ didefinisikan sebagai pasangan himpunan (V, $\mathrm{E})$, dinotasikan dengan $\mathrm{G}=(\mathrm{V}, \mathrm{E})$. Himpunan $\mathrm{V}$ adalah himpunan tidak kosong dan berhingga dari simpul-simpul dan E adalah himpunan sisi yang menghubungkan sepasang simpul. Simpul pada graf dapat dinomori dengan huruf dan bilangan asli, sedangkan sisi yang menghubungkan simpul $\mathrm{u}$ dan $\mathrm{v}$ dinyatakan dengan pasangan $(\mathrm{u}, \mathrm{v})$ atau dengan lambang e1, e2, e3. Jadi dapat dikatakan jika e adalah sisi yang menghubungkan simpul u dan simpul $\mathrm{v}$, maka e dapat ditulis sebagai $\mathrm{e}=(\mathrm{u}, \mathrm{v})$.

Berdasarkan definisi tersebut diperoleh bahwa himpunan $\mathrm{V}$ tidak boleh kosong, sedangkan himpunan $\mathrm{E}$ boleh kosong. Jadi sebuah graf dapat tidak memiliki sisi satu buah pun, tetapi simpulnya harus ada, minimal satu. Graf digunakan untuk merepresentasikan objek-objek diskrit dan hubungan antara objek-objek tersebut. Sebuah simpul/ titik/ bulatan menyatakan objeknya, sedangkan hubungan antara objek dinyatakan oleh garis.

\subsection{Jenis-Jenis Graf}

Terdapat dua jenis graf berdasarkan ada tidaknya gelang atau sisi ganda pada suatu graf, yaitu:

- Graf sederhana

Graf sederhana adalah graf yang tidak memiliki gelang maupun sisi-ganda.

\section{- Graf tak-sederhana}

- Graf ganda adalah graf yang memiliki sisi ganda, tetapi tidak memiliki loop. Sisi ganda yang menghubungkan simpul dapat lebih dari dua buah.

- Graf semu adalah graf yang memiliki loop (termasuk bila memiliki sisi ganda sekalian). Graf semu lebih umum daripada graf ganda, karena sisi pada graf semu dapat terhubung ke dirinya sendiri.

Berdasarkan orientasi arah pada sisi, graf dibedakan menjadi dua jenis, yaitu:

\section{- Graf tak-berarah}

Graf tak-berarag adalah graf yang sisinya tidak mempunyai orientasi arah.

- Graf berarah

Graf berarah adalah graf yang setiap sisinya diberikan orientasi arah.

\subsection{Terminologi Dasar Teori Graf}

Dalam pembahasan mengenai graf, banyak terminologi atau istilah khusus tentang graf yang sering digunakan, diantaranya:

\section{- Bertetanggaan}

Dua buah simpul pada graf tak berarah dikatakan bertetangga bila keduanya terhubung langsung dengan sebuah sisi. Dengan kata lain, vj bertetangga dengan vk jika (vj, vk) adalah sebuah sisi pada graf .

\section{- Bersisian}

Untuk sembarang sisi e $=(v j$, vk $)$, sisi e dikatakan bersisian dengan simpul vj dan simpul vk.

\section{- Simpul Terpencil}

Simpul yang tidak mempunyai sisi yang bersisian dengannya atau dapat juga dinyatakan bahwa simpul terpencil adalah simpul yang tidak memiliki tetangga.

\section{- Graf Kosong}

Graf yang himpunan sisinya merupakan himpunan kosong, dengan kata lain sebuah graf yang tidak memiliki sisi.

\section{- Derajat}

Derajat suatu simpul pada graf tak berarah adalah jumlah sisi yang bersisian dengan simpul tersebut dan dinotasikan $\mathrm{d}(\mathrm{vj})$. 


\subsection{Pewarnaan Graf}

Terdapat tiga macam pewarnaan graf yaitu pewarnaan titik (vertex colouring), pewarnaan sisi (edge colouring), dan pewarnaan wilayah (face colouring). Pewarnaan titik adalah memberi warna pada titik-titik graf sedemikian sehingga dua titik bertetangga mempunyai warna yang berbeda. Pewarnaan sisi-k untuk graf $G$ adalah suatu penggunaan sebagian atau semua $\mathrm{k}$ warna untuk mewarnai semua sisi di G sehingga tidak ada pasang sisi yang mempunyai titik persekutuan memiliki warna yang sama. Pewarnaan bidang adalah pemberian warna pada bidang sehingga semua bidang yang bertetangga mempunyai warna yang berbeda. Pewarnaan bidang hanya bisa dilakukan pada graf planar. Graf planar adalah graf yang dapat digambarkan pada bidang datar dengan sisi-sisi yang tidak saling memotong (bersilangan).

Banyak algoritma yang telah dikembangkan untuk membantu menyelesaikan pewarnaan graf pada pewarnaan titik, diantaranya adalah algoritma Largest Degree Ordering (LDO), Saturated Degree Ordering (SDO), dan Incident Degree Ordering (IDO). Algoritma LDO adalah algoritma yang bekerja berdasarkan pada jumlah derajat dari setiap titik. Titik yang memiliki derajat yang lebih besar diwarnai terlebih dahulu. Algoritma SDO adalah algoritma yang berprinsipkan pada jumlah warna berbeda yang ada pada tetangga-tetangga dari sebuah titik. Titik yang memiliki tetangga dengan lebih banyak warna, akan diwarnai terlebih dahulu. Algoritma IDO berprinsipkan pada jumlah tetangga yang telah diwarnai dari suatu titik. Titik yang lebih banyak bertetangga dengan titik yang telah diwarnai akan diwarnai terlebih dahulu.

\subsection{Pengaturan Lalu Lintas}

Kemacetan lalu lintas sudah terjadi dari dulu bahkan sebelum ada banyak kendaraan seperti saat ini. Perkembangan ilmu pengetahuan dan teknologi pada masalah transportasi mengakibatkan produksi kendaraan semakin meningkat. Peningkatan ini membuat kendaraan yang melintas di jalan raya semakin hari semakin banyak dan berakibat pada meningkatnya angka kemacetan.

Suatu pengaturan diperlukan untuk mengatur arus lalu lintas agar tidak terjadi penumpukan kendaraan pada persimpangan-persimpangan yang ada. Masalah tersebut menimbulkan ide untuk diciptakannya sebuah alat yang dapat mengatur lalu lintas menjadi lebih teratur. Alat ini disebut lampu lalu lintas. Pewarnaan graf dapat diaplikasikan dalam pengaturan warna lampu lalu lintas di persimpangan jalan sehingga mencegah terjadinya tabrakan di persimpangan jalan tersebut.

\subsection{Deskripsi Persimpangan Lima Kota Tua Ampenan}

Persimpangan lima yang menjadi objek penelitian pada penelitian ini adalah persimpangan yang berada di kecamatan Ampenan, Kota Mataram, yang kami sebut Persimpangan Lima Kota Tua Ampenan karena salah satu persimpangan jalannya menuju tempat wisata Kota Tua Ampenan. Persimpangan lima tersebut masing-masing adalah Jl. Saleh Sungkar (jalan menuju Senggigi), Jl. Koperasi, Jl. Yos Sudarso, Jl. Ragi Genep, dan Jl. Pabean (jalan menuju Pantai Ampenan/Kota Tua Ampenan).

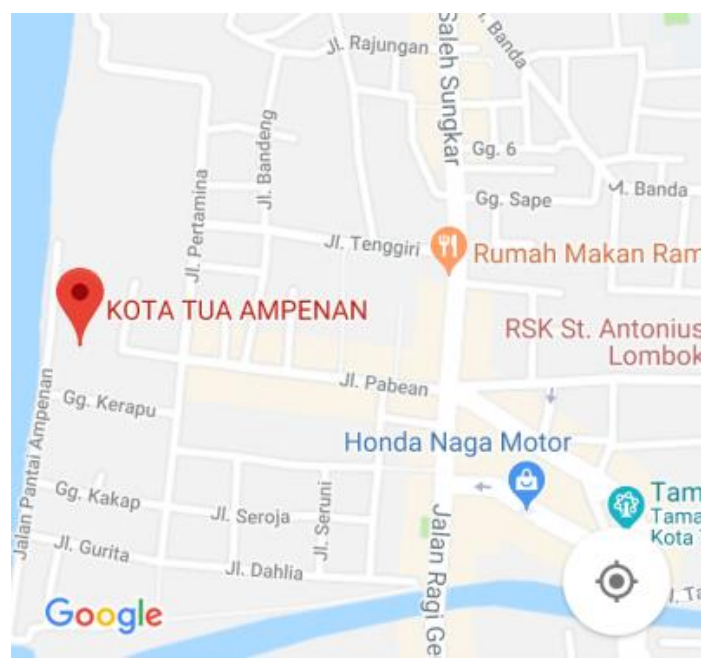

Gambar 2 - Persimpangan Terlihat di Google Maps

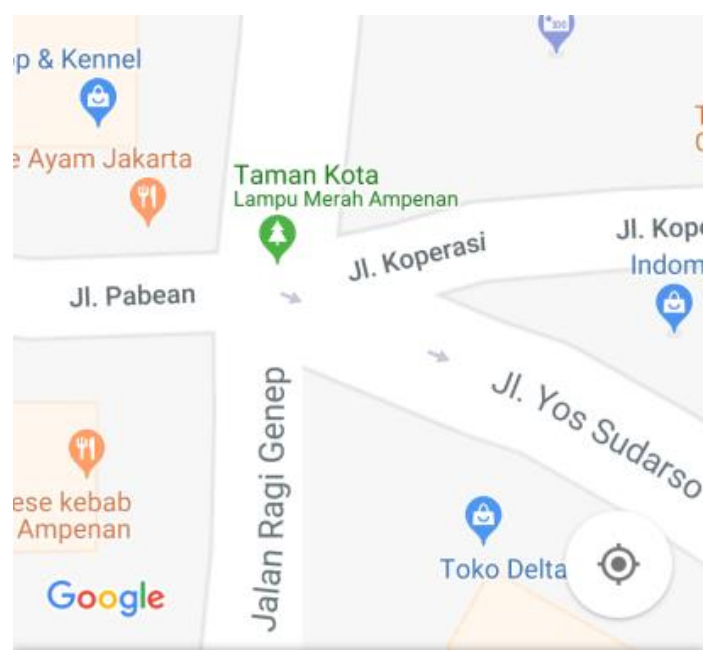

Gambar 3 - Perbesaran Persimpangan yang Dijadikan Objek Penelitian 
Pada saat pagi hari dimana jam kerja dan berangkat sekolah, serta sore, persimpangan ini padat dengan kendaraan. Pengaturan lampu lalu lintas harus diterapkan dengan baik pada persimpangan ini untuk mencegah terjadinya tabrakan ataupun penumpukan kendaraan.

Algoritma pewarnaan titik dapat diterapkan untuk menentukan pengaturan lampu lalu lintas dengan jumlah kondisi yang minimal. Tujuannya adalah untuk menentukan jalur mana yang bisa berjalan dengan memberi lampu hijau di jalan tertentu dan memberi lampu merah di jalan yang lain supaya kendaraan pada lintasan yang lain berhenti sehingga tidak terjadi tabrakan. Sedangkan, jalur langsung belok kiri diperbolehkan melintas kapan saja dan tidak berhubungan dengan warna nyala lampu lalu lintas.

\section{Metode Penelitian}

Penelitian ini adalah penelitian dasar (teoritis). Metode yang digunakan dalam penelitian ini adalah studi kepustakaan dengan menganalisis teori-teori yang sesuai dengan permasalahan yang dibahas. Langkah-langkah dalam penelitian ini adalah sebagai berikut:

a. Menelaah teori-teori mengenai graf, pewarnaan titik pada graf, serta algoritma LDO, IDO, dan SDO.

b. Mencari dan mengumpulkan hal-hal yang diperlukan sesuai objek penelitian.

c. Menentukan simpul-simpul. Simpul pada kasus ini menyatakan semua jalur yang bisa dilewati dalam persimpangan lima Kota Tua Ampenan.

d. Menentukan sisi-sisi. Sisi pada kasus ini menyatakan simpul/arus yang akan mengalami tabrakan jika digunakan bersamaan.

e. Menerapkan algoritma pewarnaan LDO, IDO, dan SDO pada graf yang sudah dibuat.

f. Membandingkan hasil pewarnaan dari algoritma LDO, IDO, dan SDO berdasarkan jumlah warna yang dihasilkan.

g. Memberikan kesimpulan akhir dari hasil penelitian.

\section{Hasil dan Pembahasan}

Pada bagian ini akan dibahas tentang perbandingan algoritma LDO, SDO, dan IDO yang diterapkan pada graf pengaturan lalu lintas di persimpangan lima Kota Tua Ampenan.

\subsection{Memodelkan Persimpangan Lima}

Persimpangan lima Kota Tua Ampenan dimodelkan menjadi gambar sederhana sehingga bisa dengan mudah dilihat arus-arus yang terdapat pada persimpangan tersebut. Model dari persimpangan lima Kota Tua Ampenan adalah sebagai berikut:

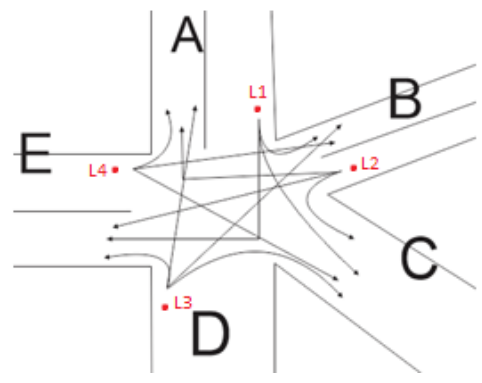

Gambar 4 - Model Persimpangan Lima Kota Tua Ampenan

Dari gambar di atas bisa dilihat pada jalan A, B, D, dan E terdapat 4 buah lampu lalu lintas, yaitu L1, L2, L3, dan L4. Lampu lalu lintas ini yang mengatur lalu lintas pada jalan-jalan tersebut. Secara berturutturut jalan A, B, C, D, dan E adalah J1. Saleh Sungkar, J1. Koperasi, J1. Yos Sudarso, Jl. Ragi Genep dan Jl. Pabean.

\subsection{Langkah-Langkah Pembuatan Graf}

Langkah pertama yang harus dilakukan adalah pembuatan simpul-simpul. Simpul disini menyatakan semua arus perjalanan yang dapat terjadi dalam persimpangan lima tersebut. Setelah dilakukan observasi diperoleh 13 simpul/arus berbeda pada persimpangan ini, yaitu $\mathrm{AB}, \mathrm{AC}, \mathrm{AE}, \mathrm{BA}, \mathrm{BC}, \mathrm{BE}$, DA, DB, DC, DE, EA, EB, dan EC.

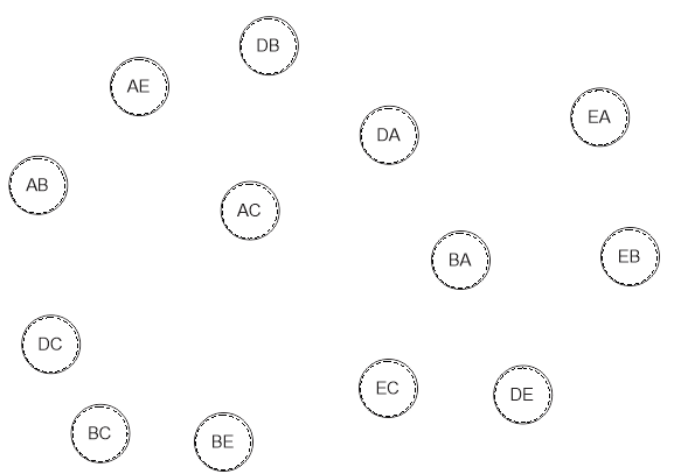

Gambar 5. Simpul-simpul pada Graf 
Langkah kedua adalah menentukan sisi untuk menghubungkan 2 simpul yang saling melintas atau berseberangan, yaitu simpul-simpul yang menunjukkan arus mana saja yang tidak bisa jalan bersamaan.

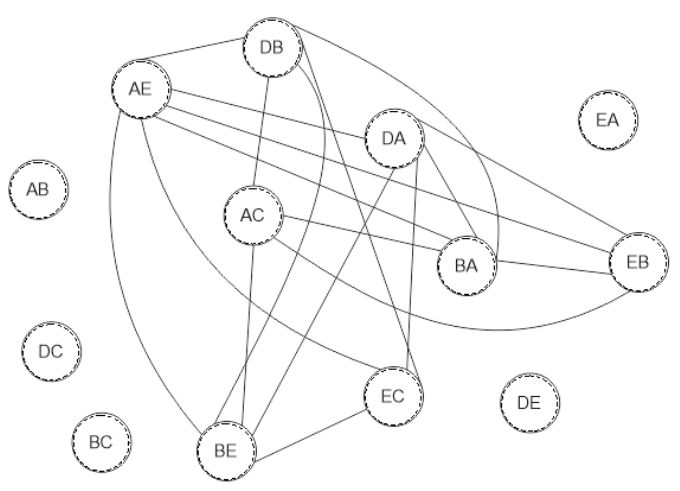

\section{Gambar 6. Graf dari Persimpangan Lima Kota Tua Ampenan}

Simpul AB, DC, BC, EA, dan DE adalah simpul terpencil yaitu yang tidak terhubung dengan simpul lain. Artinya bahwa tidak ada jalur lain yang saling melintas dengan jalur-jalur terpencil tersebut sehingga kelima jalur itu bisa berlaku lampu hijau terus.

\subsection{Langkah-Langkah Pewarnaan Graf dengan Algoritma LDO, SDO, dan IDO}

\section{a. Algoritma LDO}

Prinsip algoritma LDO adalah jumlah derajat dari setiap titik. Titik yang memiliki derajat yang paling besar diwarnai terlebih dahulu. Jumlah derajat titik $\mathrm{x}$ ditulis $\mathrm{d}(\mathrm{x})$, menyatakan banyaknya sisi yang terhubung pada titik $x$. Algoritma Welch-Powell adalah salah satu algoritma pewarnaan graf yang bekerja berdasarkan teknik $L D O$. Langkah-langkah algoritma LDO adalah sebagai berikut:

- Urutkan titik-titik pada graf dalam derajat menurun.

- Warnai titik berderajat tertinggi dengan warna 1 . Gunakan warna 1 ini untuk mewarnai semua titik yang mungkin sesuai dengan urutan derajatnya sehingga dua titik bertetangga mempunyai warna yang berbeda. Jika semua titik sudah diberi warna, langkah selesai. Jika tidak ambil warna 2.

- Warnai titik berderajat tinggi selanjutnya dengan warna 2. Gunakan warna 2 ini untuk mewarnai titik lain yang mungkin dan belum diberi warna sesuai dengan urutan derajatnya dengan syarat dua titik bertetangga tidak boleh berwarna sama. Jika semua titik sudah diberi warna, langkah selesai. Jika belum, ambil warna 3. Demikian seterusnya sampai semua titik diberi warna.

\section{b. Algoritma SDO}

Prinsip Algoritma SDO adalah jumlah warna berbeda pada tetangga-tetangga dari sebuah titik. Titik yang memiliki tetangga dengan lebih banyak warna, akan diwarnai terlebih dahulu. Derajat saturasi titik $\mathrm{x}$ ditulis $\operatorname{degs}(x)$, menyatakan banyaknya warna berbeda dari tetangga-tetangga titik x. Langkah-langkah algoritma SDO adalah sebagai berikut:

- Pilih sembarang titik pada graf, warnai dengan warna 1.

- Perbaharui himpunan titik yang belum diwarnai.

- Hitung derajat saturasi semua titik yang belum diwarnai.

- Pilih titik dengan derajat saturasi terbesar, periksa apakah titik tersebut bertetangga dengan titik yang telah diwarnai sebelumnya.

- Jika bertetangga, ambil warna 2 .

- Jika tidak, warnai titik yang telah dipilih dengan warna 1.

- Ulangi langkah di atas sampai semua titik telah diwarnai.

\section{c. Algoritma IDO}

Prinsip Algoritma IDO adalah jumlah tetangga yang telah diwarnai dari suatu titik. Titik yang lebih banyak bertetangga dengan titik yang telah diwarnai akan diwarnai terlebih dahulu. Derajat incident titik $x$ ditulis $d e \mathrm{~g}_{\mathrm{i}}(x)$, menyatakan banyaknya tetangga yang telah diwarnai dari titik $x$. Langkah-langkah algoritma IDO adalah sebagai berikut:

- Pilih sembarang titik pada graf, warnai dengan warna 1.

- Perbaharui himpunan titik yang belum diwarnai.

- Hitung derajat incident semua titik yang belum diwarnai.

- Pilih titik dengan derajat incident terbesar, periksa apakah titik tersebut bertetangga dengan titik yang telah diwarnai sebelumnya.

- Jika bertetangga, ambil warna 2.

- Jika tidak, warnai titik yang telah dipilih dengan warna 1.

- Ulangi langkah di atas sampai semua titik diwarnai. 


\subsection{Perbandingan Hasil Pewarnaan Graf}

Berikutnya akan dibandingankan hasil pewarnaan graf dari algoritma LDO, SDO, dan IDO.

a. Algoritma LDO

Berikut adalah graf yang dihasilkan dari pewarnaan dengan algoritma LDO:

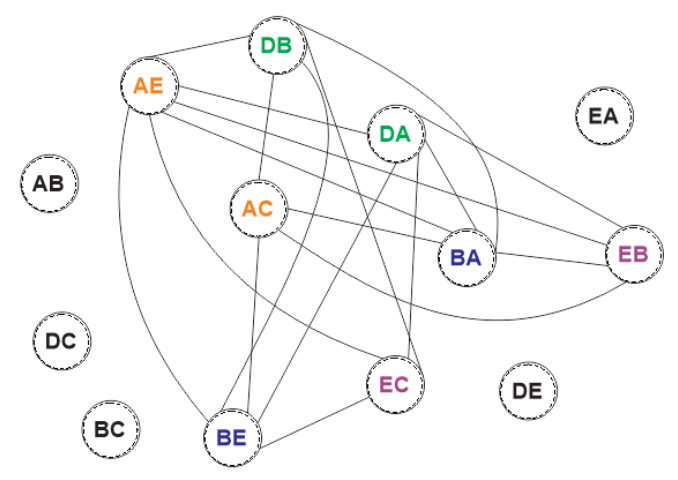

\section{Gambar 7. Pewarnaan Graf dengan Algoritma LDO}

Berdasarkan algoritma LDO diperoleh bahwa graf diatas memilik bilangan kromatis 4, karena jumlah minimum warna yang digunakan sebanyak 4 . Artinya terdapat 4 macam kondisi dalam pengaturan lampu lalu lintas. Ini akan ditunjukkan pada tabel berikut:

Tabel 1 -Lampu Lalu Lintas Kondisi 1

\begin{tabular}{|l|l|}
\hline Lampu Hijau & $\begin{array}{l}\text { DB, DA, } \\
\text { AB, DC, BC, EA, DE }\end{array}$ \\
\hline Lampu Merah & AE, AC, BA, BE, EB, EC, \\
\hline
\end{tabular}

Tabel 2 -Lampu Lalu Lintas Kondisi 2

\begin{tabular}{|l|l|}
\hline Lampu Hijau & $\begin{array}{l}\text { AE, AC } \\
\text { AB, DC, BC, EA, DE }\end{array}$ \\
\hline Lampu Merah & DB, DA, BA, BE, EB, EC, \\
\hline
\end{tabular}

Tabel 3 -Lampu Lalu Lintas Kondisi 3

\begin{tabular}{|l|l|}
\hline Lampu Hijau & $\begin{array}{l}\text { BE, BA } \\
\text { AB, DC, BC, EA, DE }\end{array}$ \\
\hline Lampu Merah & DB, DA, AE, AC, EB, EC, \\
\hline
\end{tabular}

Tabel 4 -Lampu Lalu Lintas Kondisi 4

\begin{tabular}{|l|l|}
\hline Lampu Hijau & $\begin{array}{l}\text { EB, EC } \\
\text { AB, DC, BC, EA, DE }\end{array}$ \\
\hline Lampu Merah & DB, DA, AE, AC, BE, BA, \\
\hline
\end{tabular}

Berdasarkan tabel-tabel di atas, lampu merah berarti bahwa jalur tidak boleh digunakan untuk melintas, sedangkan lampu hijau menunjukkan bahwa jalur bisa digunakan untuk melintas. Pada tabel 1, jika di jalan D lampu hijau menyala maka jalur DB dan DA boleh digunakan. Disaat yang bersamaan di jalan A, B, dan E lampu merah menyala sehingga jalur $\mathrm{AE}, \mathrm{AC}, \mathrm{BA}, \mathrm{BE}, \mathrm{EB}$, dan $\mathrm{EC}$ tidak boleh digunakan. Karena jalan $\mathrm{C}$ adalah jalan satu arah maka DC juga diperbolehkan untuk digunakan dan berlaku seperti jalur langsung belok kiri.

Selanjutnya, pada tabel 2, jika di jalan A lampu hijau menyala, maka jalur $\mathrm{AE}$ dan $\mathrm{AC}$ boleh digunakan, sedangkan jalur lainnya tidak boleh digunakan. Pada tabel 3, jika lampu di jalan B menyala hijau maka jalur BE dan BA boleh digunakan, selain itu jalur tersebut tidak boleh digunakan. Pada tabel 4, lampu menyala hijau di jalan E, sehingga jalur EB dan EC boleh digunakan, jalur lainnya tidak boleh. Karena jalur langsung belok kiri juga diperbolehkan, maka jalur AB, BC, EA, dan DE juga bisa digunakan untuk melintas dimanapun lampu hijaunya menyala.

\section{b. Algoritma SDO}

Berikut adalah graf yang dihasilkan dari pewarnaan dengan algoritma SDO:

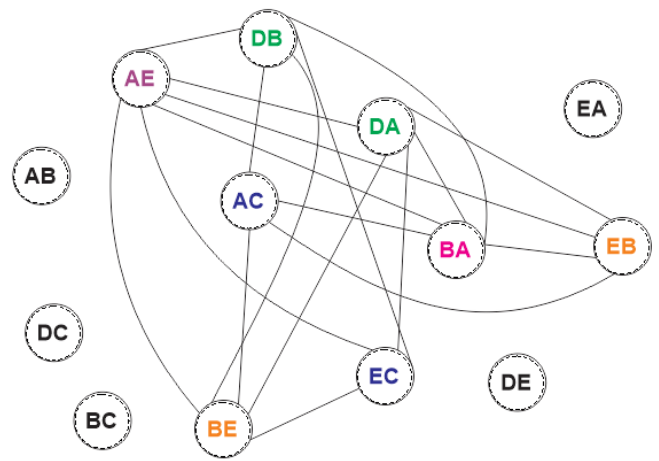

\section{Gambar 8. Pewarnaan Graf dengan Algoritma SDO}

Berdasarkan algoritma SDO diperoleh bahwa graf diatas memilik bilangan kromatis 5, karena jumlah minimum warna yang digunakan sebanyak 5 . Artinya terdapat 5 macam kondisi dalam peraturan lampu lalu lintas. Ini akan ditunjukkan pada tabel berikut:

Tabel 5 - Lampu Lalu Lintas Kondisi 1

\begin{tabular}{|l|l|}
\hline Lampu Hijau & $\begin{array}{l}\text { DB, DA } \\
\text { AB, DC, BC, EA, DE }\end{array}$ \\
\hline Lampu Merah & AE, AC, BA, BE, EB, EC \\
\hline
\end{tabular}

Tabel 6 - Lampu Lalu Lintas Kondisi 2

\begin{tabular}{|l|l|}
\hline Lampu Hijau & $\begin{array}{l}\text { AC, EC } \\
\text { AB, DC, BC, EA, DE }\end{array}$ \\
\hline Lampu Merah & DB, DA, BA, BE, EB, AE \\
\hline
\end{tabular}


Tabel 7 -Lampu Lalu Lintas Kondisi 3

\begin{tabular}{|l|l|}
\hline Lampu Hijau & $\begin{array}{l}\mathrm{AE} \\
\mathrm{AB}, \mathrm{DC}, \mathrm{BC}, \mathrm{EA}, \mathrm{DE}\end{array}$ \\
\hline Lampu Merah & $\mathrm{DB}, \mathrm{DA}, \mathrm{BE}, \mathrm{BA}, \mathrm{AC}, \mathrm{EB}, \mathrm{EC}$ \\
\hline
\end{tabular}

Tabel 8 -Lampu Lalu Lintas Kondisi 4

\begin{tabular}{|l|l|}
\hline Lampu Hijau & $\begin{array}{l}\text { BE, EB } \\
\text { AB, DC, BC, EA, DE }\end{array}$ \\
\hline Lampu Merah & DB, DA, AE, AC, BA, EC \\
\hline
\end{tabular}

Tabel 9 -Lampu Lalu Lintas Kondisi 5

\begin{tabular}{|l|l|}
\hline Lampu Hijau & $\begin{array}{l}\text { BA } \\
\text { AB, DC, BC, EA, DE }\end{array}$ \\
\hline Lampu Merah & DB, DA, AE, AC, EC, BE, EB \\
\hline
\end{tabular}

Pada tabel 5, jika di jalan D lampu hijau menyala maka jalur DB dan DA boleh digunakan. Sedangkan jalur yang lain tidak boleh digunakan. Pada tabel 6, jika di jalan A dan E lampu hijau menyala maka jalur yang boleh digunakan adalah AC dan EC. Sedangkan, jalur yang lain tidak boleh digunakan. Pada tabel 7, jika hanya di jalan A lampu hijau menyala maka semua jalur yang lain tidak dapat digunakan kecuali jalur AE. Pada tabel 8, jika jalan B dan E lampu hijau yang menyala maka jalur BE dan EB boleh digunakan, selain jalur tersebut tidak boleh digunakan. Pada tabel 9, jika lampu di jalan B menyala hijau maka jalur BA boleh digunakan dan jalur yang lain tidak boleh digunakan. Meskipun tidak disebutkan di setiap penjelasan tabel simpulsimpul terpencil atau yang menyatakan jalur langsung belok kiri selalu dalam keadaan lampu hijau atau dapat digunakan terus.

\section{c. Algoritma IDO}

Berikut adalah graf yang dihasilkan dari pewarnaan dengan algoritma IDO:

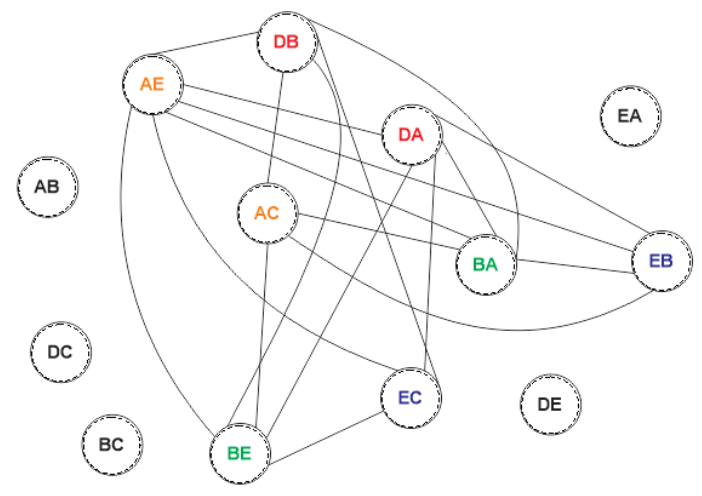

\section{Gambar 9. Pewarnaan Graf dengan Algoritma IDO}

Berdasarkan algoritma IDO diperoleh bahwa graf diatas memilik bilangan kromatis 4, karena jumlah minimum warna yang digunakan sebanyak 4 . Artinya terdapat 4 macam kondisi dalam peraturan lampu lalu lintas. Ini akan ditunjukkan pada tabel 10.

Tabel 10 -Lampu Lalu Lintas Kondisi 1

\begin{tabular}{|l|l|}
\hline Lampu Hijau & DB, DA \\
\hline Lampu Merah & AE, AC, BA, BE, EB, EC \\
\hline
\end{tabular}

Tabel 11 -Lampu Lalu Lintas Kondisi 2

\begin{tabular}{|l|l|}
\hline Lampu Hijau & AC, AE \\
\hline Lampu Merah & DB, DA, BA, BE, EB, EC \\
\hline
\end{tabular}

Tabel 12 -Lampu Lalu Lintas Kondisi 3

\begin{tabular}{|l|l|}
\hline Lampu Hijau & BE, BA \\
\hline Lampu Merah & DB, DA, , AC, EB, EC, AE \\
\hline
\end{tabular}

Tabel 13 -Lampu Lalu Lintas Kondisi 4

\begin{tabular}{|l|l|}
\hline Lampu Hijau & EB, EC \\
\hline Lampu Merah & DB, DA, AE, AC, BA, BE \\
\hline
\end{tabular}

Pada tabel 10 dari hasil pewarnaan IDO disimpulkan bahwa jika di jalan D lampu hijau menyala maka jalur DB dan DA boleh digunakan, sedangkan jalur yang lain tidak boleh digunakan. Pada tabel 11, jika jalan A yang nyala lampunya hijau maka jalur AC dan AE boleh digunakan, selain jalur tersebut tidak boleh. Pada tabel 12, di jalan B yang lampunya menyala hijau sehingga jalur BE dan BA boleh digunakan sedangkan yang lain tidak boleh. Pada tabel 13, lampu hijau menyala di jalan E sehingga jalur EB dan EC boleh digunakan sedangkan jalur yang lain tidak boleh. Meskipun tidak disebutkan di setiap penjelasan tabel simpulsimpul terpencil atau yang menyatakan jalur langsung belok kiri selalu dalam keadaan lampu hijau atau dapat digunakan terus.

Dari semua kondisi yang dihasilkan dari ketiga algoritma tersebut (dari tabel 1 - tabel 13), saat lampu merah menjadi lampu hijau kita tinggal menukar posisi jalur, sehingga jalur yang sebelumnya berlampu merah kita tukar posisi menjadi jalur berlampu hijau, dan begitu sebaliknya.

\section{Kesimpulan}

Sampai saat ini teori graf memiliki banyak terapan di berbagai persoalan dalam kehidupan sehari-hari. Salah satu contohnya adalah penggunaan pewarnaan graf pada pengaturan lampu lalu lintas di persimpangan jalan. Untuk mencari solusi dari permasalahan pengaturan lampu lalu lintas dapat 
digunakan teknik pewarnaan simpul pada graf dengan algoritma pewarnaan LDO, SDO dan IDO.

Penerapan graf pada persimpangan untuk pengaturan lampu lalu lintas adalah dengan cara (1) Merepresentasikan persimpangan jalan beserta arusnya ke bentuk graf (2) Mewarnai setiap simpul pada graf dengan menggunakan algoritma pewarnaan simpul (3) Menentukan alternatif penyelesaian pola lampu hijau dan lampu merah menyala.

Pada penelitian ini algoritma LDO dan IDO menghasilkan graf dengan bilangan kromatis 4 . Sedangkan algoritma SDO menghasilkan graf dengan bilangan kromatis 5. Bilangan kromatis ini menyatakan banyak kondisi pola warna lampu lalu lintas yang dapat diperoleh. Jadi pada kasus ini, algoritma pewarnaan LDO dan IDO lebih efektif dibandingkan algoritma SDO.

\section{DAFTAR PUSTAKA}

Diana, Erna Lus, Suryaningtyas, Wahyuni, \& Suprapti, Endang. (2016) Pengaturan Lampu Lalu Lintas di Persimpangan Jalan Ahmad Yani Giant dengan Aplikasi Pewarnaan Teori Graf, FKIP UMSurabaya.

Farhan, Muhammad. (2017) Aplikasi Pewarnaan Graf Pada Peraturan Lampu Lalu Lintas., Institut Teknologi Bandung, Indonesia.

http://www.academia.edu/6861219/ matematika_diskrit-pewarnaan_graf

Munir, R. 2016. Matematika Diskrit. Bandung: Informatika.

Sari, Khairani P., Armiati, \& Mirna. Perbandingan Algoritma Pewarnaan LDO, SDO, dan IDO pada Graf Sederhana, Universitas Padang, Indonesia. 